\title{
Strained aromatic oligoamide macrocycles as new molecular clips
}

\author{
Hua Jiang, Jean-Michel Léger, Philippe Guionneau and Ivan Huc*
}

\section{Supporting Information}

\section{Procedure for the synthesis of the macrocycles.}

Under a nitrogen atmosphere, 8-amino-4-isobutoxyl-2-quinolinecarboxylic acid $^{1}$ (220 mg, $0.85 \mathrm{mmol})$, lithium chloride $(85 \mathrm{mg}, 2 \mathrm{mmol})$, and triphenyl phosphite $(0.22 \mathrm{~mL}, 0.85 \mathrm{mmol})$ were dissolved in a mixture of $\mathrm{N}$-methyl pyrrolidone $(1.7 \mathrm{~mL})$ and pyridine $(0.43 \mathrm{~mL})$. The mixture was heated at $100^{\circ} \mathrm{C}$ for $3 \mathrm{~h}$. After cooling, it was poured onto water $(10 \mathrm{~mL})$. A precipitate formed and was collected by centrifugation, dried, and then purified by flash chromatography $\left(\mathrm{SiO}_{2}\right)$ eluting with toluene-ethyl acetate (from 97:3 to 93:7 vol:vol) to give trimeric macrocycle $3(40 \mathrm{mg}, 20 \%)^{2}$ and tetramer macrocycle 4 (40 mg, 20\%). ${ }^{2}$

Cyclic trimer 3. $\mathrm{Mp}>250^{\circ} \mathrm{C}$. ${ }^{1} \mathrm{H}$ NMR $\left(400.13 \mathrm{MHz}, \mathrm{CDCl}_{3}\right): \delta=10.52(3 \mathrm{H}, \mathrm{s}), 8.79(3 \mathrm{H}, \mathrm{d}$, $J=8.0 \mathrm{~Hz}), 7.84(3 \mathrm{H}, \mathrm{d}, J=8.0 \mathrm{~Hz}), 7.68(3 \mathrm{H}, \mathrm{s}), 7.41\left(3 \mathrm{H}, \mathrm{dd}, J_{\mathrm{a}}=J_{\mathrm{b}}=8.0 \mathrm{~Hz}\right), 3.98(6 \mathrm{H}$, $\mathrm{d}, J=6.7 \mathrm{~Hz}), 2.28(3 \mathrm{H}, \mathrm{m}), 1.16(18 \mathrm{H}, \mathrm{d}, J=6.7 \mathrm{~Hz}) ;{ }^{13} \mathrm{C} \mathrm{NMR}\left(100.62 \mathrm{MHz}, \mathrm{CDCl}_{3}\right): \delta=$ 163.99 , 162.35, 151.11, 139.33, 133.97, 126.68, 121.97, 120.80, 116.98, 100.32, 74.95, 28.15, 19.25; IR (liquid layer): $v=3381,2960,2930,2874,1675,1597,1568,1522,1504,1470$, $1418,1395,1355,1324,1249,1110,1046,874 \mathrm{~cm}^{-1}$; TOF-MS: $m / z=727.29\left[\mathrm{M}+\mathrm{H}^{+}\right], 749.25$ $\left[\mathrm{M}+\mathrm{Na}^{+}\right], 765.17\left[\mathrm{M}+\mathrm{K}^{+}\right]$. Crystals suitable for X-ray diffraction analysis were grown upon slow evaporation of a $\mathrm{MeOH}-\mathrm{CH}_{2} \mathrm{Cl}_{2}$ solution.

Cyclic tetramer 4. $\mathrm{Mp}>250^{\circ} \mathrm{C} .{ }^{1} \mathrm{H}$ NMR $\left(400.13 \mathrm{MHz}, \mathrm{CDCl}_{3}\right): \delta=10.32(4 \mathrm{H}, \mathrm{s}), 8.09(4 \mathrm{H}$, $\mathrm{d}, J=8.7 \mathrm{~Hz}), 8.01(4 \mathrm{H}, \mathrm{d}, J=7.6 \mathrm{~Hz}), 7.62(4 \mathrm{H}, \mathrm{s}), 7.51\left(4 \mathrm{H}, \mathrm{dd}, J_{\mathrm{a}}=J_{\mathrm{b}}=8.0 \mathrm{~Hz}\right), 4.04$ $(4 \mathrm{H}, \mathrm{m}), 3.97(4 \mathrm{H}, \mathrm{m}), 2.24(4 \mathrm{H}, \mathrm{m}), 1.08(24 \mathrm{H}, \mathrm{m}),{ }^{13} \mathrm{C} \mathrm{NMR}\left(100.62 \mathrm{MHz}, \mathrm{CDCl}_{3}\right): \delta=$ $164.47,163.17,151.52,141.97,134.06,126.64,124.97,122.79,119.27,99.43$, 75.15, 29.67, 28.01, 19.10. IR (liquid layer): $v=3302,2959,2925,2872,2854,1689,1590,1573,1532$, 1507, 1488, 1469, 1420, 1396, 1383, 1358, 1326, 1261, 1218, 1110, 1046, 873, 803, $760 \mathrm{~cm}^{-}$ 1; TOF-MS: $m / z=969.21\left[\mathrm{M}+\mathrm{H}^{+}\right], 991.19\left[\mathrm{M}+\mathrm{Na}^{+}\right], 1007.13\left[\mathrm{M}+\mathrm{K}^{+}\right]$. Crystals suitable for $\mathrm{X}$-ray diffraction analysis were grown upon slow diffusion of $\mathrm{n}$-hexane into a chlorobenzene solution.

\footnotetext{
${ }^{1}$ Jiang, H.; Léger, J.-M.; Dolain, C.; Guionneau, P.; Huc. I. Tetrahedron 2003, 59, 8365-8374.

${ }^{2}$ Based on consumed starting amino-acid.
} 


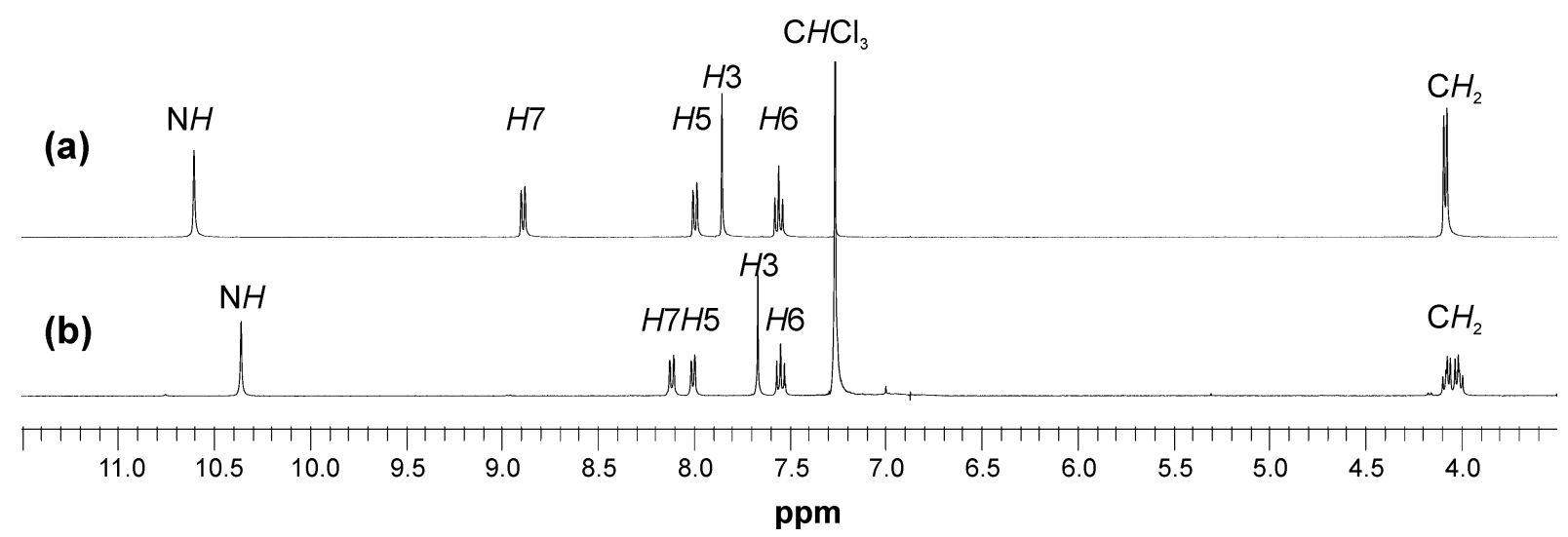

SI Figure 1. Part the $400 \mathrm{MHz}{ }^{1} \mathrm{H}$ NMR spectra of 3 (a) and 4 (b) in $\mathrm{CDCl}_{3}$. Note the chemical shift differences of $\mathrm{NH}, \mathrm{H} 3$, and $\mathrm{H} 7$, consistent with a tilt of the amide groups out of the plane of the quinoline rings in tetramer 4. Also note the diastereotopic patterns of $\mathrm{CH}_{2}$ groups in $\mathbf{4}$.

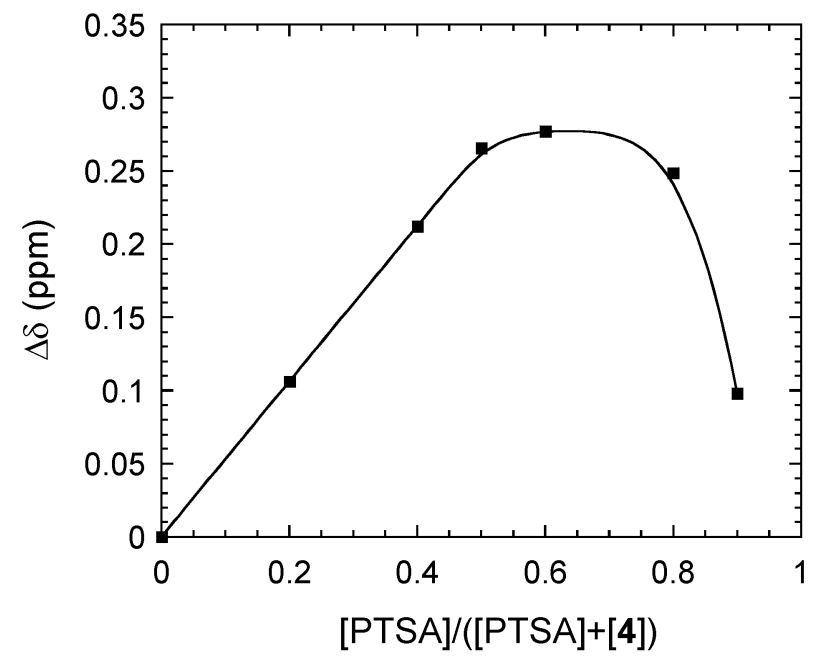

SI Figure 2. Job plot of $10 \mathrm{mM}$ (total concentration) mixtures of tetramer 4 and PTSA monitored by ${ }^{1} \mathrm{H} \mathrm{NMR}$ in $\mathrm{CDCl}_{3} / \mathrm{CD}_{3} \mathrm{OD}$ (99:1 vol:vol). The line is for guiding the eye only. 
(a)

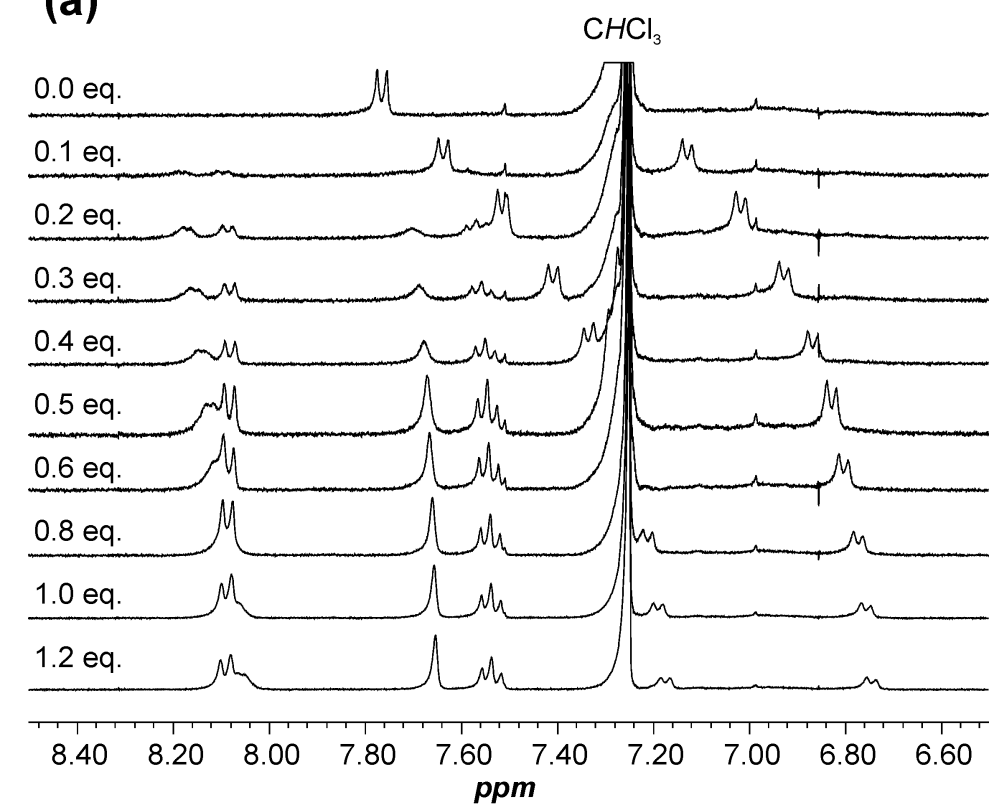

(b)

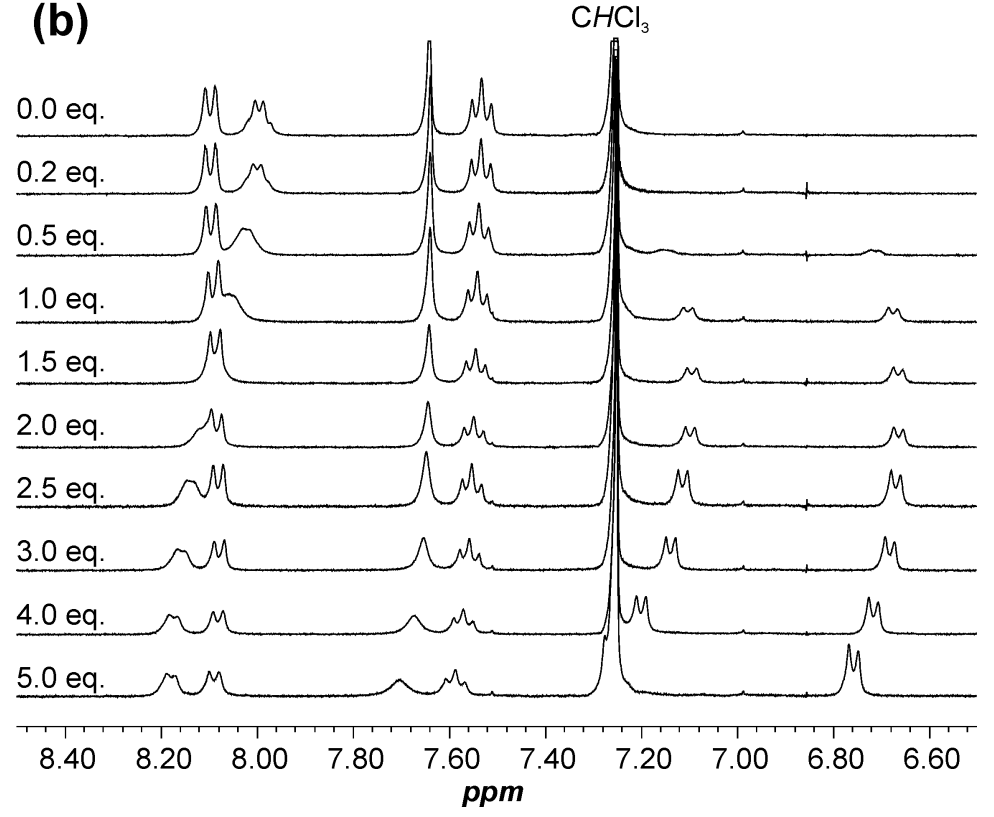

SI Figure 3. Part of the $400 \mathrm{MHz}{ }^{1} \mathrm{H}$ NMR spectra (aromatic region) of mixtures of $\mathbf{4}$ and PTSA in $\mathrm{CDCl}_{3} / \mathrm{CD}_{3} \mathrm{OD}$ (99:1 vol:vol) at $25^{\circ} \mathrm{C}$ : (a) titration of a $1 \mathrm{mM}$ solution of PTSA with a $10 \mathrm{mM}$ solution of $\mathbf{4}$; (b) titration of a $1 \mathrm{mM}$ solution of $\mathbf{4}$ with a $10 \mathrm{mM}$ solution of PTSA. 


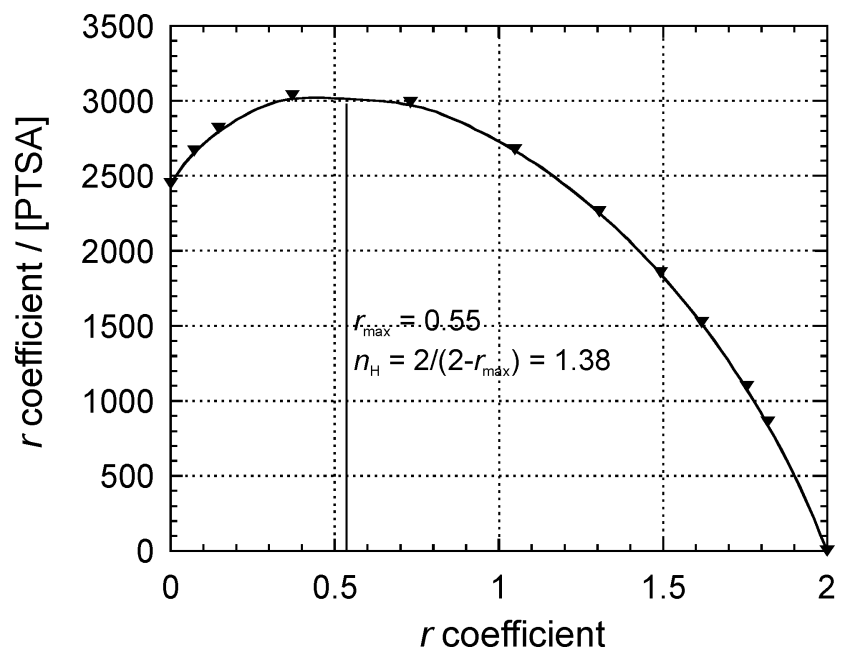

SI Figure 4 Scatchard plot $^{3}$ derived from the titration of $\mathbf{4}$ by PTSA shown in Figure 3b.

${ }^{3}$ G. Scatchard, Ann. N. Y. Acad. Sci. 1949, 51, 660. 